\title{
Common Purpose and Conspiracy Liability in New Zealand: Criminality by Association?
}

\author{
Julia Tolmie and Kris Gledhill*
}

\begin{abstract}
Case law interpreting the common purpose aspect of party liability and the law on conspiracy in New Zealand (as set out in ss 66(2) and 310 of the Crimes Act 1961 (NZ)) has created a situation of over-reach. Individuals who have a limited relationship to criminality carried out by another or in a group context are potentially caught by extended liability rules that can lead to a poor association between the moral culpability of a defendant and serious criminal liability. Indeed, it is suggested that these forms of liability risk guilt by association rather than on the basis of individual positive fault: we suggest that New Zealand's judges, following and sometimes expanding upon interpretations from other common law jurisdictions, have lost sight of the core concept of individual fault.
\end{abstract}

\section{INTRODUCTION}

A fundamental premise of the criminal law is that an individual's liability (and resulting punishment) is based on their own individual action and personal fault: association with criminals is not itself criminal unless specified circumstances are met. ${ }^{1}$ This substantive rule is reinforced by rules of procedure and evidence that protect against guilt by association. A prime example is the caution in using hearsay evidence, things said outside the presence of the defendant.

Having said this, there are offences based on joint liability and liability for participation in another's offending. These recognise that group dynamics or support may elevate the risk and seriousness of the principal's offending. Such forms of liability and offences can be found

* The authors would like to thank participants at the symposium at which the papers in this special edition were first presented in draft, particularly Professor Jeremy Finn of the University of Canterbury, who took on the role of designated commentator and made a number of useful suggestions; we also thank the peer reviewers, one of whom in particular made a number of useful suggestions.

1 The UK Supreme Court in $R v$ Jogee [2016] UKSC 8, [77] said, 'It is important to emphasise that guilt of crime by mere association has no proper part in the common law'. Statutory exceptions to this principle include s 6 of the Summary Offences Act 1981 (NZ), which makes it an offence to associate with convicted thieves but only if the circumstances are such that another crime of dishonesty is likely to result and only if the person has been given three warnings about the risk of a charge. These are restrictive circumstances. Sections $6 \mathrm{~A}$ and $6 \mathrm{~B}$ have similar provisions relating to violent offenders and serious drug offenders. 
in the provisions for party liability, and in particular common purpose liability, and the offence of conspiracy.

Thus, s 66(1) of the Crimes Act 1961 (NZ) provides for principal liability $^{2}$ and also for secondary liability for aiding, abetting, inciting, counselling and procuring. ${ }^{3}$ In addition, s 66(2) provides that:

Where 2 or more persons form a common intention to prosecute any unlawful purpose, and to assist each other therein, each of them is a party to every offence committed by any one of them in the prosecution of the common purpose if the commission of that offence was known to be a probable consequence of the prosecution of the common purpose.

Furthermore, s 310(1) of the Crimes Act 1961 creates an offence for:

[E]very one who conspires with any person to commit any offence, or to do or omit, in any part of the world, anything of which the doing or omission in New Zealand would be an offence. ${ }^{4}$

These are not objectionable in so far as they criminalise a defendant for their individual involvement in and personal mental commitment to the crime that is agreed upon or actually committed. In Part II we set out the rationale for extending liability to situations where the defendant may have done nothing to directly contribute to criminal offending. This rationale for both common purpose party liability and conspiracy is based on the defendant's act of agreement or support, accompanied by the mens rea of intention, in respect of the common unlawful purpose or the offence to which the conspiracy is directed. In Part III we go on to describe how this need for individual fault has been potentially eroded by judicial development of the actus reus and mens rea requirements of conspiracy and common purpose liability in New Zealand and associated issues of proof. In Part IV we discuss the implications of this and, in particular, the concerns that it raises about criminal overreach.

This discussion is relevant to other jurisdictions that have similar offences of conspiracy and common purpose party liability. For example, Victoria's statutory definition of conspiracy in s 321 of the Crimes Act 1958 (Vic) employs the same core concepts that are articulated in the New Zealand common law on conspiracy. And whilst Victoria's recently enacted version of common purpose party liability in ss 323-324 of the Crimes Act avoids some of the problems we set out in relation to the New Zealand provision it still employs similar concepts and is vulnerable to judicial dilution along similar lines.

\footnotetext{
$2 \quad$ Crimes Act 1961 (NZ) s 66(1)(a).

$3 \quad$ Crimes Act $1961(\mathrm{NZ}) \mathrm{s}$ 66(1)(b)-(d).
}

4 There is a maximum penalty of seven years' imprisonment if the substantive offence carries seven years or more, and otherwise the same as the substantive offence. There are also various specific conspiracies, which may have a different sentence regime or may not involve a specific offence and so be outside s 310 : see s 116 (conspiracy to defeat justice); there is also conspiracy to do a treasonable act contrary to s 73(f), which, by reason of s 74, carries 14 years rather than the life sentence for acts amounting to treason. 
We hope in this article to add some practical heft to academic discussions about the fault requirement and the degree to which the criminal law in New Zealand preserves or undermines it.

\section{The Rationale for Criminal Liability}

\section{A Conspiracy}

There is no definition of conspiracy in s 310 of the Crimes Act 1961 (NZ). In Mulcahy $v$ The Queen, Willes J, rejecting a contention that overt acts pursuant to a conspiracy were needed, defined conspiracy as 'the agreement of two or more to do an unlawful act'. ${ }^{5}$ He added that, whilst a mere intention to commit a crime was not a crime, the agreement to carry the intention into effect 'is an act in itself, punishable if for a criminal object or for the use of criminal means'. ${ }^{6}$ This was accepted by the New Zealand Court of Appeal in $R v$ Gemmell, ${ }^{7}$ which, following Mulcahy, said that whilst the unlawful act had to be a criminal offence, ${ }^{8}$ a conspiracy:

$[\mathrm{C}]$ onsists in an intention which is common to the mind of the conspirators and the manifestation of that intention by mutual consultation and agreement among them ... to put the design into effect. ${ }^{9}$

Similarly, s 321 of the Crimes Act 1958 (Vic) requires an agreement to pursue a course of conduct that will produce an offence with an intention that the offence be committed.

This early start to criminalisation - as soon as an agreement is made, with no need for proximity to the offending in contemplation or even overt acts towards it - is justified on the basis that the "number and the compact give weight and cause danger' ${ }^{10}$ This width to liability explains why the definition offered in Mulcahy and endorsed in Gemmell sets relatively strict requirements for agreement: 'mutual consultation and agreement' leading to a 'common design to commit some offence'. The exemplar of this is a group involved in identified offending pursuant to a formulated agreement (even if the only real evidence of this is the actions taken pursuant to the agreement).

$\overline{5 \quad \text { (1868) LR } 3}$ HL 306. A summary of the earlier development of the law, with relevant citations, can be found in $R v L K ; R v R K$ (2010) 241 CLR 177, [59]-[61] (French CJ).

6 (1868) LR 3 HL 306, 317.

7 [1985] 2 NZLR 740.

8 This would exclude anything that amounted only to a tort, for example, or more importantly the common law conspiracies to carry out acts that were not necessarily criminal but viewed as illegal, such as the conspiracy to corrupt public morals. [1985] 2 NZLR 740, 743. Hardie Boys J in $R v$ Sew Hoy [1994] 1 NZLR 257, 267 said that 'the essence of conspiracy is an intention to agree coupled with a common design to commit an offence, that is, to put the design into effect'. also led to the conclusion that a conspiracy to commit an offence by impossible means is nevertheless a crime: see $R v$ Sew Hoy [1994] 1 NZLR 257, 267. 


\section{B Common Purpose Party Liability}

Under s 66(1) of the Crimes Act 1961 (NZ) a person can be a secondary party to a completed offence by assisting or encouraging another's offending before or contemporaneously with the offence being committed. The secondary party must also intend to assist or encourage the principal to commit the offence ${ }^{11}$ with knowledge of the essential matters that constitute the offence. ${ }^{12}$ The second pathway, the common purpose doctrine or joint enterprise liability under s 66(2), is different. It requires a 'common intention to prosecute any unlawful purpose and to assist each other therein', the commission of crimes by a principal 'in the prosecution of the common purpose'; and knowledge by the secondary party that the crime planned or any additional crime was 'a probable consequence of the prosecution of the common purpose'. ${ }^{13}$

The difference between s 66(1) and (2) was noted by the New Zealand Court of Appeal in Bouavong $v$ The Queen: $:^{14}$ under s 66(1) the accused must actually assist or encourage the offence for which they are held liable, whereas under s 66(2) they need not provide any assistance or encouragement (and may even conceivably provide active discouragement) in respect of any incidental offending that occurs. Furthermore, whilst liability based on aiding and abetting requires the most culpable forms of mens rea - knowledge and intention ${ }^{15}$ - the mens rea requirement for the common purpose doctrine is merely subjective foresight of the probable risk of an incidental crime occurring. ${ }^{16}$ These more relaxed requirements are said to be justified by the party already being a wrongdoer because they committed to the common unlawful purpose from which any incidental offending foreseeably flows. Simester explains why a commitment to the common purpose is the key to the reduced requirements for liability under s 66(2):

By forming a joint enterprise, [D] signs up to its goal. In doing so, she accepts responsibility for the wrongs perpetuated in realizing that goal, even though they be done by someone else. Her joining with $\mathrm{P}$ in a common purpose means that she is no longer fully in command of how the purpose is achieved. Given that $\mathrm{P}$ is an autonomous agent, [D] cannot control the precise manner in which $\mathrm{P}$ acts. Yet her commitment to the common purpose implies an acceptance of the choices and actions that are taken by $\mathrm{P}$ in the course of realizing that purpose. ${ }^{17}$

$11 \quad R v$ Wentworth [1993] 2 NZLR 450; $R v$ Shaw and Snelleksz [2009] NZHC 2314; $R v$ Pene CA, 1 July 1980.

$12 R v$ Singh and Singh [2003] NZCA 289.

13 Waho $v$ The Queen [2005] NZCA 68, [6].

14 [2014] 3 NZCA 484.

15 Note that the older authority of Cooper $v$ Ministry of Transport [1991] 2 NZLR 693 suggests a watering down of the requirement of intention and knowledge, at least in respect of 'unknowable facts,' but this does not sit with the recent Supreme Court decision in Edmonds v The Queen [2012] 2 NZLR 445, [25].

$16 \quad R v$ Hamilton [1985] 2 NZLR 245; $R v$ Renata [1992] 2 NZLR 346, 349.

17 Andrew Simester, 'The Mental Element in Complicity' (2006) 122 Law Quarterly Review 578, 580-600. 
In short, $\mathrm{P}$ becomes an agent for $\mathrm{D}$ in the execution of the joint purpose. Importantly, this means that $\mathrm{D}$ has to accept the risk of a bad outcome to which they have no high level of mental commitment. ${ }^{18}$

This agency principle seems also to be a theme for the extended coverage of conspiracy liability that we describe below: in essence, those who make a bad choice by joining the criminal plans of a group of malcontents should know that, even if the agreement is only to engage in a small part of the plot, it may produce responsibility for more, and it allows the others to speak for them even when that is hearsay. ${ }^{19}$

If liability is to be based on individual fault, and the central rationale for extending criminal liability to crimes the defendant has not directly participated in is the defendant's commitment to that offending or the offending that it flows out of, then it follows that compelling evidence of an agreement or commitment to the common unlawful purpose on the part of the individual defendant should be required before they are convicted of conspiracy or on the basis of common purpose party liability.

\section{Eroding the Need to Prove Agreement AND AWAREnEss}

\section{A Conspiracy}

Since conspiracy was first defined, judges have favoured prosecution arguments about the need for it to be used beyond the exemplar of a group involved in identified offending pursuant to a formulated agreement. Judges have determined that defendants can be co-conspirators with people whose identity and role they do not know; that the agreement does not have to be proven because its existence and scope can be inferred from actions taken by the defendant and the alleged co-conspirators; and that hearsay statements by alleged co-conspirators can be used to link the defendant to the conspiracy. We elaborate on these points here.

It has been determined that a conspiracy has an ongoing existence: this has the effect of enhancing the value of a conspiracy charge in securing liability. For example, an agreement made outside New Zealand but put into effect in New Zealand provides jurisdiction for conspiracy rather than (or as well as) any substantive offence in New Zealand. ${ }^{20}$ It also means that people can join the agreement and so do not have to be involved from the outset. In $R v$ Sanders, ${ }^{21}$ the Court of Appeal rejected an argument

18 Whilst the person must foresee the incidental offending, as a matter of human nature belief in the best outcome is natural even when the worst is foreseen.

19 In relation to s 66(1) see also s 70(2): if the secondary party liability arises from prompting another to do something as a principal rather than helping them to do what they have decided to do, there can be liability if the principal takes a different but predictable course.

20 See Director of Public Prosecutions $v$ Doot [1973] AC 807; $R v$ Johnston (1986) 2 CRNZ 289; $R v$ Sanders [1984] 1 NZLR 636; $R$ v Darwish [2006] 1 NZLR 688.

21 [1984] 1 NZLR 636. 
that since the offence is complete once the agreement is made, only those involved at the outset can be guilty in relation to the specified conspiracy. ${ }^{22}$

Moreover, conspiracies need not involve the members knowing each other. For example, there may be a wheel arrangement, whereby one or more persons at the centre make arrangements with various others (the spokes of the wheel) in furtherance of the plan. ${ }^{23}$ An alternative may be a chain of people who deal with their immediate links in the chain only. In such a case, a significant question may be what the conspiracy is to which each defendant is a party: in particular, is there a single conspiracy or a series; and if there are various offences involved, is a particular link in the chain or spoke in a wheel a party to the entire enterprise or just a part of it? ${ }^{24}$ Strict proof in relation to the agreement would provide the answer to this, but this is not required.

We suggest that the original concept of 'mutual consultation and agreement' has effectively been abandoned in substance: there is no requirement that it be proved. In DPP v Bhagwan, Lord Diplock commented that the law of conspiracy 'rests upon the legal fiction that the offence lies not in the overt acts themselves which are injurious to the common weal but in an inferred anterior agreement to commit them'. ${ }^{25}$ But as Lord Bridge in $R v$ Anderson observed 'it is a matter of common experience in the criminal courts that the "terms" of a criminal conspiracy are hardly ever susceptible of proof". ${ }^{26}$ Rather than this causing the prosecution difficulty in proving conspiracy beyond a reasonable doubt, it becomes permissible to infer the fact and terms of the agreement from the combined conduct of the alleged parties. ${ }^{27}$ As Somers J noted in $R v$ Humphries: ${ }^{28}$

The proof of conspiracy - a conscious common design to do an unlawful act or to do a lawful act by unlawful means - may be inferred from the separate

22 It may also be that a person becomes involved in an arrangement which is not known by them to be problematic, but then discovers that it is aimed at something criminal and at that point forms the necessary criminal intent. There will be no problem of a lack of concurrence of actus reus and mens rea because of the continuing nature of the offence. For example, in $R v$ Harris [2006] NZCA 273, [66], Williams J for the Court of Appeal endorsed the direction of the trial judge that 'people can join or leave a conspiracy at various stages of its overall existence' and that an accused could 'become a party to an already existing [conspiracy] if he co-operates knowingly to further its objective'.

23 In $R v$ Meyrick and Ribuffi (1929) 21 Cr App R 94, 101, Lord Hewart CJ noted that in order that people may conspire together it is not necessary that there should be direct communication between each and all, and so it was a matter of evidence on the facts as to whether there was one large conspiracy or a series.

24 Note also the existence of the statutory offence of being involved in a criminal group, set out in s 98A of the Crimes Act 1961 (NZ).

25 [1972] AC 60, 79. Note also Willes J in Mulcahy (1868) LR 3 HL 306, 317, citing Grose $\mathrm{J}$ in $R \cup$ Brisac and Scott (1803) 4 East 164, 171, indicating that it is generally a matter of inference, deduced from certain criminal acts of the parties accused, done in pursuance of an apparent criminal purpose in common between them'.

26 [1986] AC 27.

27 Ibid, 38.

28 [1982] 1 NZLR 353. 
acts of the persons charged when those acts demonstrate that such persons were acting together in concert. ${ }^{29}$

Hence, in Gemmell, where the defendant's action consisted of driving robbers to the scene knowing that they were planning a robbery, the Court of Appeal found that it had been proper for the judge to direct the jury that it was for them to determine whether this was a casual act of driving or evinced an intention to join a conspiracy. ${ }^{30}$

Indeed, conduct that is a minor part - 'real and not insignificant' - of what is required to put the offence into practice is sufficient to become a party to an agreement. ${ }^{31}$ This means that there is no need to be a member of the conspiring group, since assisting the aims of the group is sufficient.

Moreover, proving a conspiracy is made easier for the prosecution by substantive and evidential rules. At the substantive level, case law equates knowledge of the facilitation of criminal conduct with an agreement to join it. ${ }^{32}$ This has arisen in the context of inter-related conspiracies in a chain of commerce, as when stolen goods or illegal drugs are passed on. For example, a wholesaler of drugs may be part of a conspiracy to sell at the street level by virtue of facilitating the latter activity. In $R v$ Morris, ${ }^{33}$ two men who had imported cocaine into Dunedin sold some of it on to a third man, Morris, for him to re-sell in Christchurch. Blanchard $\mathrm{J}$, for the Court of Appeal, indicated that the 'metes and bounds' of the conspiracy involved assessing what was the "common intention or common understanding' of the conspirators. This meant that if they were part of a chain of distribution, the conspiracy involved the on-sales of the drug by Morris. ${ }^{34}$

The evidential rule is also illustrated in Morris, namely the ready admission of statements made when a person is not present that would otherwise be treated with caution because they are hearsay. In Morris,

29 Ibid, 356. There might be instances in which too many assumptions have to be made: for example, in $R v$ White [1945] GLR 108, it was determined that the passing of a wallet into the pocket of another, which wallet contained what looked like folded cards of coupons, was an insufficient basis to find there was a conspiracy to utter forged coupons because too many assumptions had to be made as to existence of agreement to commit crime.

30 [1985] 2 NZLR 740, 745.

$31 \quad R v$ Greenfield [2002] NZCA 12: posting letters to two addresses to validate them for a future import of drugs sufficient to join the conspiracy.

$32 R v$ Richards (1992) 9 CRNZ 403. This seems to go even further than playing a part in some of the conduct required by the conspiracy, noted above. Here it is possible to become a conspirator by providing the opportunity for another offence that will be carried out without any input from the facilitator. Note the contrasting approach in the context of causation: a person is not responsible for the autonomous choice of another adult merely because they have set up the circumstances in which that person has chosen to act: $R v$ Kennedy [2007] 3 WLR 612 (overturning a manslaughter conviction in the case of the man who supplied the drug to another who died by injecting himself with the drug).

33 [2001] 3 NZLR 759.

34 Ibid, [26]. 
the prosecution had evidence of drug paraphernalia (but no drugs beyond traces) and of various links by Christchurch-based Mr Morris with the men in Dunedin, which did not prove much. However, evidence of conversations between the Dunedin wholesalers to which Morris was not a party revealed that Morris was involved with them as a recipient of their wholesale supplies, the conversations apparently being to the effect that Morris would not re-sell the drugs in Dunedin. The Court of Appeal determined that, so long as there was independent evidence on the balance of probabilities of the existence of a conspiracy, the comments of the wholesalers were admissible against Morris to show that he was a conspirator with them in relation to the sales that would take place in Christchurch.

The co-conspirators rule has been expressly preserved by s $12 \mathrm{~A}$ (a) of the Evidence Act 2006 (NZ). ${ }^{35}$ Furthermore, it has been extended by the Supreme Court which confirmed that there is no need for independent evidence of the conspiracy to the civil standard. Qui Jiang $v$ The Queen ${ }^{36}$ determined that all that is required is reasonable evidence that allows a judge to say that it is safe to admit the hearsay material. The basis for the admissibility of such evidence is the idea of agency: namely that the co-conspirators have authority to speak for each other. ${ }^{37}$

\section{B Common Purpose Party Liability}

The New Zealand courts have similarly evolved common purpose liability in a manner that arguably dilutes the need for clear proof of the defendant's commitment to the criminal offending. In particular, the courts have been vague about what must be established on the facts to prove that the individual defendant joined the common purpose, have permitted vague and generic formulations of the common unlawful purpose and any incidental offending and have diluted the mens rea requirements set out in the statute. We elaborate on these points here.

Beatrice Krebs ${ }^{38}$ suggests that the requirements of accessorial liability under s 66(1) must be met in order to establish that a person has joined a common purpose, because the common purpose doctrine was originally

35 This provision preserves the rules of the common law relating to the admissibility of statements of co-conspirators or persons involved in joint criminal enterprises.

36 [2008] 1 NZLR 1, overturning $R v$ Buckton [1985] 2 NZLR 257. See also $R v$ Messenger [2008] NZCA 13; [2011] 3 NZLR 779 and Wu $v$ The Queen [2011] 3 NZLR 764.

37 In $R v$ Humphries [1982] 1 NZLR 353, 356, it was explained that 'agreement between the parties implies authority in each to act or speak to attain the agreed object of all' (and so the comments as to hearsay statements apply also to acts done that reveal what the conspiracy is). This was endorsed by the Supreme Court in Qui Jiang [2008] 1 NZLR 1, [24].

38 Beatrice Krebs, 'Joint Criminal Enterprise' (2010) 73(4) Modern Law Review 578, 580 . 
designed to be exculpatory ${ }^{39}$ rather than inculpatory. ${ }^{40}$ In short, the offence that formed the common purpose would have to be proved to the standards set out in s 66(1)(b)-(d). Section 66(2) would then only apply to an offence that was a predictable extension of the s 66(1) liability. ${ }^{41}$

The New Zealand case law does not support this. The majority of the Supreme Court in $A$ hin ${ }^{42}$ simply referred to the need to prove that 'there was a shared understanding or agreement to carry out something that was unlawful; and the person(s) accused of being parties to that agreement had all agreed to help each other and participate to achieve their common unlawful goal'. ${ }^{43}$ That such an agreement to help would be sufficient to satisfy the requirements of s 66(1)(d)-(e) was, however, acknowledged by William Young $\mathrm{J}$ in Ahsin in the following terms: ${ }^{44}$

When two people agree to prosecute an unlawful purpose and to assist in its implementation, each of them thereby encourages the other to commit the proposed crime and is potentially liable under s 66(1)(c). Where such people actually assist in the implementation of the common purpose, s 66(1)(b) is potentially engaged..$^{45}$

Ahsin overturned the Court of Appeal in Bouavong $v$ The Queen ${ }^{46}$ which held that s 66(2) did not apply where the offence that was the object of the unlawful purpose and the offence committed in the prosecution of the unlawful purpose were the same. The Court of Appeal in Bouavong had arrived at this conclusion so as to avoid undermining s 66(1) by allowing 'a much broader potential liability for parties than that prescribed under subs (1)'. ${ }^{47}$ In spite of the unquestionable logic of William Young J's comments (noted above), the majority in Ahsin clearly contemplated that a person could be found to have joined the common purpose at a lower threshold than would be required to establish liability under s 66(1)(b)-(d).

39 Ibid. See also John Smith, 'Criminal Liability of Accessories: Law and Law Reform' (1997) 113 Law Quarterly Review 453, 462-463.

40 There is limited case law on this: hence, the Justice Select Committee, UK House Of Commons, Joint Enterprise: Eleventh Report of Sessions 2010-12 (HC 1597, 17 January 2012) Vol 1, [33] has called for 'guidance on the proper threshold at which association potentially becomes evidence of involvement in crime'.

41 This was the position recently taken by the New Zealand Court of Appeal in Bouavong $v$ The Queen [2014] 2 NZLR 23, [74], [98]-[99]. After Ahsin v The Queen [2014] NZSC 153, [89], [101], Bouavong can no longer be taken as good law on this point.

42 [2014] NZSC 153.

43 Ahsinv The Queen [2014] NZSC 153, [102]. The words used in s 66(2) are 'where two or more persons form a common intention to prosecute any unlawful purpose, and to assist each other therein'. See also Waho v The Queen [2005] NZCA 68, [6].

44 [2014] NZSC 153, [221]. See also [249], [295]. This was also acknowledged by the UK Supreme Court in $R v$ Jogee [2016] UKSC 8, [78].

45 Note that William Young $J$ saw the issue in terms of the overlap between the provisions but it could equally be characterised as an issue of the dovetailing interface between the provisions.

47 Ibid, [105]. 
The majority in Ahsin $v$ The Queen ${ }^{48}$ reasoned that s 66(2) could apply to scenarios where the parties had only planned one offence because:

Parliament cannot have contemplated that s 66(2) was confined to offences other than those intended at the time of entry into the common purpose. If that were so, there would be circumstances where participants in a common purpose resulting in the exact crime intended could not be charged under s 66 at all, because assistance or encouragement could not be attributed with certainty to any individual. Such participants are at least as culpable as those involved in a common purpose that results in an unintended but foreseen offence. ${ }^{49}$

If, as is suggested by the wording of the section, it is necessary to establish that each individual defendant agreed to pursue the common crime and to assist in its implementation before they can be liable under s 66(2) then, as pointed out by William Young $\mathrm{J}$ but contrary to what is implied by this majority statement, liability under s 66(2) should be impossible unless, at the very least, encouragement of the common purpose offence can be attributed beyond reasonable doubt to an individual defendant.

The mens rea that is logically required to establish an agreement to prosecute a crime should include both knowledge of what is agreed to and an intention that the agreement be executed. This is essentially what is required under s 66(1)(b)-(d) (knowledge of the essential matters of the offence and an intention to assist or encourage the principal in committing it). Articulating the mens rea required under s 66(2) in this manner would inject clarity and rigor into the application of the section. ${ }^{50}$ However, the courts have not clarified the mental state that is required on the part of each alleged party in relation to the common unlawful purpose.

In addition, it should be noted that the Supreme Court in Qui Jiang ${ }^{51}$ made it clear that the agency basis for allowing hearsay evidence to link

48 [2014] NZSC 153, [28], [38] (Elias CJ); [90], [97] (McGrath, Glazebrook and Tipping JJ); [239] (William Young J).

49 Ibid, [94]. Note that Elias CJ and William Young J employed different reasoning. Elias CJ appears to suggest at [28] that in circumstances of opportunistic offending the common purpose crime and the incidental offending might be the same under s 66(2), but it is not clear that that is an argument for the application of s 66(2) over s 66(1) when there is only one offence, as opposed to a description of how s 66(2) might operate if it was applied to such a set of facts. William Young $J$ reasoned that $\mathrm{s} 66(1)(\mathrm{b})-(\mathrm{d})$ is a subset of $\mathrm{s}$ 66(2) at [237] and therefore in cases involving uncertain evidence - for example, where it is not clear what the scope of the common purpose is - it is simpler to direct the jury in terms of $s 66(2)$ than framing the alternative factual possibilities in terms of multiple provisions at [240]. This rests on the decision that s 66(2) absorbs rather than dovetails with $\mathrm{s}$ 66(1) and it requires reading an alternative mens rea possibility (similar to that required under s 66(1)) into s 66(2). His position is different from the majority who appear to read s 66(2) not as absorbing s 66(1) but providing an alternative and broader form of liability.

50 Andrew Ashworth, Principal and Secondary Party Liability (Oxford University Press, 5th ed, 2006) 428, also stresses the importance of being 'able to state clearly what the element of agreement necessary to qualify as a joint venture is'. [2008] 1 NZLR 1. 
the defendant to an agreement to commit a crime is equally applicable to the common unlawful purpose under s 66(2).

Victoria has recently codified its common purpose doctrine. ${ }^{52}$ Before a defendant can be convicted under the statutory version contained in ss 323-324 of the Crimes Act 1958 (Vic) ${ }^{53}$ they must have intentionally assisted or encouraged or directed' the commission of an offence ${ }^{54}$ or entered into 'an agreement, arrangement or understanding with another person' to commit an offence. ${ }^{55} \mathrm{In}$ addition, they must be 'aware that it was probable that the offence charged would be committed in the course of carrying out [this] other offence'. The legislature has therefore expressly provided that liability is contingent on two offences with proof that the individual offender had a clear commitment to the primary offending from which the incidental but predicted offending flows. It is to be hoped that Victorian judges learn from the mistakes made in jurisdictions such as New Zealand and do not adopt an overly broad interpretation of this and the other requirements of this provision.

Traditionally the common unlawful purpose required by s 66(2) was thought to be a specific crime. ${ }^{56}$ However, in Edmonds $v$ The Queen the Supreme Court allowed the common purpose to be characterized as pursuing a group in order 'to cause serious violence to somebody in the group' ${ }^{57}$ Whilst this was 'closely associated with the charge of participation in an organized criminal group to which the appellant pleaded guilty', it was not defined so as to actually specify a specific crime or crimes..$^{58}$

The degree of correspondence that has to occur between what was agreed to or foreseen by the party before the offending taking place, and what actually happened when the principal executed the common purpose, is another issue on which the New Zealand courts have chosen to widen rather than contain potential liability under the common purpose doctrine. Clearly agreement and prediction down to minute detail cannot be required, given the need for improvisation and the many different ways people will act. ${ }^{59}$ However, at some point, offending that goes beyond what was agreed means there is no longer a commonality of purpose and the

52 The common law doctrine of common purpose is abolished by $\mathrm{s} 324 \mathrm{C}$ of the Crimes Act 1958 (Vic) enacted in the Crimes Amendment (Abolition of Defensive Homicide) Act 2014 (Vic).

53 Inserted by the Crimes Amendment (Abolition of Defensive Homicide) Act 2014 (Vic).

54 Crimes Act 1958 (Vic) s 323(1)(b).

55 Crimes Act 1958 (Vic) s 323(1)(d).

56 Similarly, a conspiracy has to involve a specific offence; the existence of the conspiracy to defeat justice in a separate section, $\mathrm{s} 116$, is explicable because it does not require an agreement to commit an offence.

57 [2012] 2 NZLR 445, [9].

58 Ibid. This statutory offence - set by s 98A of the Crimes Act 1961 (NZ) - is an example of an ongoing criminal enterprise, which is what conspiracy liability has become: see the discussion above. See also Waho v The Queen [2005] NZCA 68, [6], where the common purpose was defined as being to 'deal out retribution' and 'to deliver violence in retaliation'.

See, for example, $R v$ Te Moni [1998] 1 NZLR 641. 
principal must be regarded as being on a frolic of his or her own. Drawing this line involves a value judgment and hence indeterminacy in the law. This judgment will be affected by the court's interpretation of the breadth or narrowness of the crime or crimes agreed upon and hence what is considered beyond the scope of that agreement. The less specific the agreement, the more likely an incidental crime will not be outside its scope. For example, if the common purpose is interpreted as being to burgle particular premises on a particular date in order to steal certain types of property, then if the principal enters different premises on a different day to assault someone that would be a departure from the prosecution of the common purpose. But if the common purpose is interpreted on this set of facts as being simply to burgle, this action by the principal might be within its scope, even if the secondary party was expecting a different date and location, and would certainly be so if the entry was also to steal.

Similarly, there is a question of whether common purpose liability requires the prediction of the same or similar actions as those carried out by the principal in committing the incidental crime, or whether it merely requires prediction of the generic offence that actually occurred even if the manner that it occurred involved very different actions to those that were foreseen by the defendant. This has commonly arisen in situations in which the principal has used a weapon that was not part of the plan.

Determining what the common purpose is (as with conspiracy) invariably a matter of inference. Hence, in Edmonds the court noted that sometimes evidence that a party was carrying or knew about a weapon might be the only evidence of a shared common purpose. ${ }^{60}$ However, the court suggested that it might also be the case that 'the common purpose may be best assessed by reference to the results the defendants intended to bring about', which could result in an inference that the common purpose was 'to inflict serious, and potentially life-threatening violence in whatever way was convenient'. ${ }^{61}$ In this case an expectation that injury would be inflicted by kicks to the head would allow liability for an injury inflicted with a weapon that one of the group had but which the defendant did not know about. ${ }^{62}$

This focus on foresight of the generic legal offence that actually took place, ${ }^{63}$ even if its factual details were quite different from what was foreseen and carried a higher degree of risk, ${ }^{64}$ is different from the approach that had been taken in England before the recent abolition of the common

60 Edmonds v The Queen [2012] 2 NZLR 445, [50].

61 Ibid.

62 Ibid, [51].

63 See, for example, Reddy v The Queen [2011] 3 NZLR 22, [39]. On this approach the accused would avoid liability only if what took place amounted to a different kind of generic offence from that foreseen. See Andrew Simester and Warren Brookbanks, Principles of Criminal Law (Thomson Reuters, 4th ed, 2012) 196.

64 Or the predicted weapon is used but in a different way to that which was predicted (for example, not to frighten but to kill); Attorney General's Reference Under Section 36 of the Criminal Justice Act 1972, No 3 of $2004 v$ The Queen [2006] Crim LR 63; $R$ v Uddin [1999] QB 431. 
purpose doctrine in that jurisdiction. ${ }^{65}$ The English approach had focused on the nature of the actions that were foreseen by the party. ${ }^{6}$ By way of contrast the New Zealand Supreme Court in Edmonds $v$ The Queen definitively held that there is no legal requirement that the secondary party foresee the use of the exact weapon that was wielded by the principal, or even a weapon of similar lethality, in order to be liable as a secondary party in respect of its use. ${ }^{67}$ The court found that what was material was that the accused knew that the ultimate result (meaning the generic crime in issue) was probable rather than that he foresaw 'the exact concatenation of events ${ }^{\prime 68}$ which, in the end, brought that result about.

[Section 66(2)] recognises only one relevant level of risk, which is the probability of the offence in issue being committed. If the level of risk recognized by the secondary party is at that standard, it cannot matter that the actual level of risk was greater than recognized. ${ }^{69}$

The flexibility and simplicity of this approach has been lauded by some. For example, Edmonds $v$ The Queen has been described as 'a welcome return

65 The UK Supreme Court in $R v$ Jogee [2016] UKSC 8, [77] held that common purpose party liability was not part of the law in England. It was influenced in part by the concern that it invited guilt by association.

$66 \quad R v$ Powell; $R v$ English [1999] 1 AC 1; $R v$ Rahman [2009] 1 AC 129; $R v$ Mendez [2011] QB 876; $R v$ Uddin [1999] QB 431. In England it was considered that if the principal's specific conduct which comprised the actual offending was of a 'fundamentally different' nature from the act which was predicted by the party, then the party cannot be held accountable for the offending on the basis that it is either a departure from the common purpose or that they lack the necessary mens rea because the incidental crime was not foreseen: see $R v$ Mitchell [2009] 1 Cr App R 31. The English Court of Appeal in $R v$ Mendez, above, determined that the specific actions of the principal will be 'fundamentally different' if they are actions which are more violent or involve a different level of dangerousness than acts of the nature which the alleged party foresaw. Amy Hill has characterised the English approach as a 'process-focused approach', which places 'emphasis on the way the crime is inflicted and the defendant's knowledge of the likelihood of that conduct'. She characterises the more recent New Zealand approach as an 'outcome-focused approach' which focuses on 'the more general harmful outcome that the defendant knowingly risked through participation in the unlawful enterprise'. See Amy Hill, 'Knowledge of the Weapon in Party Liability Cases: An Analysis of Edmonds $v$ R' (2013) 44 Victoria University of Wellington Law Review 167, 172. It could be more accurate to see the contrast between characterising offences in terms of how they manifest in particular factual events, as opposed to characterising offences in terms of the generic set of legal requirements that establish criminal liability (which could be satisfied by any number of particular factual incidents). For example, a defendant may commit three robberies - these incidents all meet the generic legal requirements for robbery set out in s 234(1) of the Crimes Act 1961 (NZ) - yet they are also three separate distinct robberies in that they are individual factual manifestations of these legal requirements.

67 Edmonds v The Queen [2012] 2 NZLR 445. See also Waho $v$ The Queen [2005] NZCA 68; $R v$ Vaihu [2009] NZCA 111.

68 Edmonds $v$ The Queen [2012] 2 NZLR 445, [54].

69 Ibid, [47]. 
to fundamental principles ${ }^{70}$ and defended ${ }^{71}$ on the basis that it gives effect to the plain words of s 66(2).$^{72}$ Defenders of the ruling argue that the prior English focus on matching the specifics of what the party foresaw with what actually happened adds a layer of complexity to an already difficult area and generates tests that are indeterminate. ${ }^{73}$ Further, the English approach produces inconsistent results from case to case, and has led to the development of criteria that do not accurately reflect the degree of harm that the party knew was risked under the common purpose. ${ }^{74}$

Certainly, the principle set out in Edmonds is simple to state. However, it is possible to generate simplicity by restricting rather than expanding the scope of group liability doctrines, and to do so is consistent with the core principle underlying criminal liability, namely that punishment should flow from proper proof of individual participation in an offence.

The clarity of Edmonds is matched by its coverage. Whilst liability for what actually happened, even if it was unpredictable in the details, should attach to all those who agreed or acknowledged that the offence should be put into practice by any means possible (as may have been the case in Edmonds), ${ }^{75}$ frequently this will not be the proven agreement. After Edmonds, foresight that a particular offence might occur will result in liability even if the offence plays out in a radically different and

$70 \quad$ Simester and Brookbanks, above n 63, 199.

71 See Hill, above n 66, for a sustained defence which makes many of the points repeated here.

72 The words of the section require that the party foresaw 'the commission of [the incidental] offence' not the specific details of its execution. Note that it is possible to argue that the word 'offence' as it is used in s 66(2) could mean the specific incident of offending that was agreed to and/or contemplated by the party rather than the generic offence. The fundamental difference rule as developed in England could be seen as an attempt to give expression to this alternative interpretation.

73 Edmonds v The Queen [2012] 2 NZLR 445, [46]. The court thought that tests as to whether the weapon that was foreseen was fundamentally different in lethality are indeterminate both legally and factually. Even if there was stability in the judicial approach to the factors that are material to the application of the test, each case is, in the end, a value judgment for the jury.

74 Ibid, [45]. The court thought that knowledge of the specific weapon or its equivalent does not bear a precise correlation to the accuracy of the party's foresight of the risk of death or serious injury. The likelihood of serious injury or death predominantly depends not on the type of weapon used in an assault but the personalities and intention of those engaged, their states of emotional arousal and whether they have consumed alcohol or drugs etc. Note that it could be argued that the English 'fundamental difference' rule discussed in Edmonds is not confined to an examination of the type of weapon that was used, but is a more general normative inquiry encompassing the manner in which the weapon was used. Thus potentially increasing the range of other specific factual issues traversed in Edmonds as being relevant in elevating the degree of risk that was foreseen by the party. See Andrew Simester, John Spencer, Bob Sullivan and Graham Virgo, Simester and Sullivan's Criminal Law: Theory and Doctrine (Hart, 4th ed, 2010) 238.

75 See also Reddy $v$ The Queen [2011] 3 NZLR 22, [46], where the clear intention was to cause enough bodily harm to the victim in order to hospitalise them. 
unexpected way. ${ }^{76}$ This may extend liability too far. Kirby J, dissenting in the High Court of Australia in $R v$ Keenan, described this as defining an offence at a 'high, and virtually inescapable level of generality'. ${ }^{77} \mathrm{He}$ said this abstracted the issues to such a level that they become self-referential and removed 'from any real decision in the trial (usually by a jury) the proper consideration of whether the primary offender has departed completely from the concerted action envisaged in the prosecution of the common purpose of the offenders' ${ }^{78}$ To give an example, a generic offence of intentional wounding can extend from the merest breaking of the skin to a life-threatening wound that is just short of a homicide. Under the approach taken in Edmonds, if the defendant foresees a cut they may be taken to foresee a serious wounding. Concerns about the over-inclusive operation of the common purpose doctrine in relation to homicide are compounded by the fact that the party may not be required to foresee death to be convicted of manslaughter or felony murder. They will be liable for manslaughter so long as they foresee the generic assault that actually caused death regardless of whether they foresee the specific actions that constituted that assault. ${ }^{79}$

In the real world, people do not think in terms of whether conduct amounts to a criminal offence: rather, they think of actions and consequences of actions. Kirby $\mathrm{J}$ argued that confining criminal liability to situations where a party foresees the offence, in the sense that they foresee the particularity of the conduct of the principal, reflects community justice in that it gives the jury a real, appropriate and proper role in setting the bounds of notional criminal liability under the common purpose doctrine. He also said that it affords criteria of criminal liability susceptible to precise proof in the trial, which is attractive in an area of the law already replete with subtleties and complexities. And it invites a differential assessment of the respective criminal culpability of the co-offenders, rather than drawing all participants in conduct of fluid criminality into an undifferentiated liability, risking excessive and unjust penalties for those who have limited individual culpability in respect of the offending that actually occurred. Finally, it avoids extending the ambit of the fiction that imposes upon one person liability for the act of another, to actions which they may not have intended or expected to happen. ${ }^{80}$

It has been recognised that in order to establish agreement to or awareness of the risk of a generic offence it might still be necessary to explore what specific actions an alleged party agreed to or foresaw happening. Thus, William Young $\mathrm{P}$ in $R v$ Vaih $u,{ }^{81}$ having commented

$76 \quad$ Contrary to the example provided by Simester and Brookbanks, above n 63, 197.

$77 \quad R v$ Keenan [2009] HCA 1, [64].

78 Ibid, [68].

$79 \quad R$ v Rapira [2003] 3 NZLR 794 (CA); $R$ v Hartley [2007] 3 NZLR 299; Edmonds $v$ The Queen [2012] 2 NZLR 445, [27].

$80 \quad R v$ Keenan [2009] HCA 1, [66].

$81 R v$ Vaihu [2009] NZCA 111. See also $R v$ Ma'u; Redman [2008] NZCA 117, [26]; $R v$ Hirawani; Wilson and Henry (unreported, NZCA, 20 November 1990). 
that appreciation that grievous bodily harm was proposed might not need knowledge that someone was armed, added that sometimes: "it will not be possible for a rational jury to infer the required knowledge in relation to a particular defendant unless sure that the defendant was aware that members of his party were armed'. ${ }^{82}$ Amy Hill also suggests that trial judges, whilst not required to as a matter of legal principle, may frequently give conservative jury directions requiring that a party have knowledge that a principal has a weapon if a weapon is actually used for practical reasons concerned with providing juries with clear directions on the facts, avoiding appeals and giving the defendant a fair trial. ${ }^{83}$ However, such directions also reflect unease about overly inclusive rules risking the imposition of serious criminal liability merely because the accused was the member of a group that included the offender and should have foreseen something wrongful.

Section 66(2) requires that the alleged party subjectively foresaw, as a probable consequence of pursuing the common purpose, the commission of the incidental crime. This requires the Crown to prove that the accused committed to the common purpose with personal awareness of the high risk of any incidental offending. In fact, the courts have arguably watered down the requirement for foresight of a probable risk by interpreting that phrase to mean an appreciation that the incidental offending "could well happen'. ${ }^{84}$ Furthermore, foresight on the part of the accused is frequently inferred from the common purpose that is determined to exist and what is logically predictable from that. ${ }^{85}$

Not surprisingly, the growth of conspiracy from its inchoate beginnings has provided a flexibility that led Lord Brown in $R v$ Saik to note that conspiracy is 'often referred to as "the prosecutor's darling". ${ }^{86}$ And, as this description of recent developments in the common purpose doctrine has demonstrated, the same could be said of common purpose party liability (which also benefits from the evidential rules noted above, as made clear by Qui and s $12 \mathrm{~A}$ of the Evidence Act 2006 (NZ)).

\section{The Implications of Extended Liability}

In Part II, we suggested that the rationale for extending the defendant's criminal liability to crimes that have not yet been committed, and those which have been committed by someone else, is that the defendant agreed

82 Ibid, [88]. See also $R v$ Leuluaialii (unreported, NZCA, 22 November 2006). In $R$ $v$ McNaughton [2012] NZHC 815, [28] it was accepted that on the facts this was a case in which the Crown had to prove that the parties knew of the gun to have foresight of the incidental crime.

83 Hill, above n 66, 185-186.

$84 R v$ Gush [1980] 2 NZLR 92 (CA), [94]; Reddy $v$ The Queen [2011] 3 NZLR 22, [49].

85 In $R v$ Ma'u; Redman [2008] NZCA 117, [69] it was said that 'an inference of foresight will quite readily be drawn; voluntary participation in a criminal enterprise ordinarily permits just such an inference'.

[2007] 1 AC 18, [123]. 
to the offence (or the offence which gave rise to the ultimate offending) taking place, whilst having the intention that this occur. The defendant thus lent weight to the risk of the offence occurring, and authorised those who might actually commit it to act on their behalf in respect of the offending itself and foreseeable contingencies (such as further incidental offending).

Then, in Part III, we traced judicial developments in the law on conspiracy and common purpose party liability to argue that the courts have weakened the need to prove individual agreement on the part of the defendant in such cases. In other words, we have suggested that judicial developments have potentially undermined the rationale for extended liability in some cases.

We described considerable extensions from the original conception of conspiracy liability. These extensions allow for inherently vague and flexible arrangements - agreements or understandings ${ }^{87}$ - which do not require specific proof because inference is inevitably all that is possible. It becomes possible to infer from the conduct proven that there must have been an agreement, even though the very basis for extending criminal liability to agreements is because a proven plot is dangerous. The fact and scope of an agreement can instead be inferred by collating the actions of the alleged co-conspirators that suggest the joint pursuit of a crime. The defendant can then be found to have joined this agreement if their actions can be interpreted as supporting some aspect of the overall agreement, notwithstanding that they are not part of the group and have come in at some point after the others and do not know who the others are. Furthermore, proof to the criminal standard that an individual was a party to a conspiracy may be based on evidence provided by their co-conspirators that might well be inadmissible in relation to a substantive charge.

Likewise, the case law is vague about the actus reus and mens rea requirements for s 66(2) party liability and, particularly, what commitment must be demonstrated by an individual defendant in relation to the shared unlawful purpose. By suggesting that something less than a s 66(1) commitment to the common purpose is required the courts have opened the possibility that: (i) an individual defendant can be inferred to have joined the common purpose from their presence and some behaviour that can be interpreted as supportive of the group aims; and (ii) the scope of the common purpose that they have joined can then be inferred by collating the actions of the group, including any offending that actually occurred. Hearsay statements by the principal and other parties are also admissible in this process.

The position is made more critical by two further developments: (i) the common purpose can be understood as a generic offence rather than any more specific course of conduct that is agreed upon, and may even be interpreted to include any one of a range of potential generic offences; and (ii) the prosecution can invite the inference that the offending that occurred must have been personally foreseen by the defendant if the 
generic offence it represents was objectively predictable as a consequence of pursuing a vague and generally expressed common unlawful purpose. ${ }^{88}$ Each of these generous interpretations of the statutory language marks a step away from the core principle that individual fault should be based on that individual's contribution and commitment to the criminal offending.

If the pre-requisites for criminal liability - the clarity of the agreement/ enterprise and the involvement of the defendant in it - are undermined, there is an enhanced risk that we are extending serious criminal liability to a situation involving little more than association. For example, a failure to explain how an association is innocent or to realise the risk arising from suspicious circumstances and take positive steps to publicly dissociate may be the essence of a successful prosecution case for conspiracy. In other words, if a person has links with one or more others who are engaged in criminal activity those links could be used to infer that the person is - essentially that they must be - a member of the conspiracy.

Equally common purpose liability cases could involve situations where a person has an ongoing relationship (friendship or family) with an offender and is in their company on an occasion where the principal commits an offence. This will be particularly so if the defendant has engaged in some prior anti-social behaviour whilst in the principal's company. For example, liability for manslaughter can be found when a young man is hanging out with a group of friends who get into a physical confrontation with another group of men and someone in his group kills a person in the other group. Liability for murder can be found when a woman whose partner is a violent gang member is driving him and other associates around in a car - shouting abuse at rival gang members - and he tells her to stop the car and gets out to attack a stranger whom he mistakes for a gang member. It could potentially extend to another female associate sitting in the back seat who participated in shouting insults and who knew that her companions were patched members of a gang that had a culture endorsing the use of violence. ${ }^{89}$ Liability in these circumstances can begin to look like it rests on a failure by the defendant to appreciate that they are in the vicinity of something improper and publicly dissociate themselves from the offender or offenders. ${ }^{90}$ Effectively this is an obligation to act and liability for a failure to do so - rather than liability based on criminal offending or a clear commitment to criminal offending by the defendant.

Another concern raised by the increased flexibility and breadth of conspiracy and common purpose party liability is that these doctrines

88 This risk is compounded by a judicial watering down of the statutory standard of risk for foresight of the ancillary offences set out in s 66(2). The statute requires foresight of the offending as a probable consequence - which the courts have interpreted to require foresight that the offending 'could well happen': $R v M a$ ' Redman [2008] NZCA 117, [69]-[74].

89 See the facts of Ahsin [2014] NZSC 153 as they pertain to Ms Rameka for an illustration of these possibilities.

90 But see Nicola Lacey, 'Space, Time and Function: Intersecting Principles of Responsibility Across the Terrain of Criminal Justice' (2007) 1 Criminal Law and Philosophy 233. 
could be used by the prosecution to sidestep the difficulties of proving individual fault in relation to the substantive offences. There has long been the practice, for example, of charging a group of people with party liability when it is clear that someone in the group was the principal but there is no evidence linking any particular individual to the substantive offending. ${ }^{91}$ Conspiracy could also be used as a substitute for the substantive offence where proof presents an obstacle or could be added onto substantive charges to take advantage of the more flexible rules of evidence.

Conspiracy may be used in three broad situations: first, when the authorities have been able to intervene before the substantive offence has been completed: here the criminality is the risk of harm that was created by the agreement itself. In the two others, some offending will have occurred but (i) more may be planned, or (ii) the conspiracy has come to an end. In all these situations, but particularly these last two, there may be a combination of the conspiracy charge with a substantive charge. ${ }^{92}$ This may have sensible applications: for example, in $R v$ Henry the defendant was convicted of a single burglary in the context of a plan to burgle around 50 houses, revealed by evidence found after his arrest. ${ }^{93}$ A higher sentence was imposed for the conspiracy to demonstrate the true criminality on this set of facts. Similarly, if one of the conspirators does not play their agreed part, it might be proper to have a conviction for conspiracy even if they are not liable for the full offence, as was the case in relation to one defendant in $R v$ Dillon; $R v$ Cowie.$^{94}$

Courts in England and Wales, which have also endorsed the use of a conspiracy charge in place of a series of substantive offences, have identified one valid reason for its use instead of a charge for the completed offence. In $R v$ Saik, Lord Hope noted that:

Dealing with a series of completed criminal acts by charging the defendant with conspiracy is a device. Its aim is to ensure that the entire course of conduct is brought under scrutiny in one count and that, when it comes to sentence, the defendant is punished for the totality of his criminal activity. ${ }^{95}$

$91 \quad R v$ Witika [1993] 2 NZLR 424. This possibility is specifically permitted by legislation in Victoria: Section 324B of the Crimes Act 1958 (Vic) makes it clear that the offenders role in the offending need not be determined.

92 In the first scenario, there may have been a precursor offence - for example, possession of articles designed for improper purposes, importation of precursor substances for drug manufacturing and the like.

93 [1997] 1 NZLR 150.

94 [1956] NZLR 110. The Court of Appeal noted in relation to Mr Dillon, who was acquitted of various substantive counts, that a conviction for conspiracy to defraud was proper. Indeed, it was suggested that it was proper to include the conspiracy provision in case the evidence did not allow a conviction on the specific offences alleged to have been part of the conspiracy at [113]. Conspiracy to defraud - no longer part of New Zealand law - did not require that the conspirators had a specific offence in mind; however, a specific offence has to be in mind in most conspiracy cases and so it would be unusual for the agreement not to amount to encouragement or participation of the sort that would found secondary liability.

95 [2007] 1 AC 18, [41]. Further, at [84] he noted that this was not something that was necessary in Scotland because it was possible for a single charge to be 
This is the Henry situation, already noted: but there is no suggestion that the device is so limited. This brings the risk of the prosecution leading evidence of a number of specific instances of similar criminal conduct to invite the inference of an agreement that encompasses a wider range of conduct. The New Zealand High Court has - albeit tentatively - gone further than allowing a prosecution that reveals the proper level of criminality. ${ }^{96}$ In $R v$ Richards (Conspiracy) the prosecution suggested that a conspiracy charge should be available to deal with the alleged existence of an organised group of drug manufacturers because substantive charges might be too easily avoided by the difficulties of proving possession or manufacture if drugs were not actually found. ${ }^{97}$ Fisher $\mathrm{J}$ found 'substance' in the suggestion that the inclusion of conspiracy as an offence in the Misuse of Drugs Act 1975 meant that Parliament had recognised that it might be easier to prove a conspiracy charge (intention and agreement) than the substantive offences or the necessary party liability, particularly in light of the co-conspirators rule. ${ }^{98}$ As noted above the co-conspirators rule allows the prosecution to show some reasonable evidence of a criminal enterprise and then use hearsay evidence to convict a particular defendant.

The risks that arise from the flexible nature of the conspiracy charge have, of course, been recognised by occasional calls from judges to limit the use of such charges where the agreement has been put into effect. ${ }^{99}$

\section{CONCLUSION}

In this article we have raised the possibility that judicial developments of the law on conspiracy and party liability mean that little more than presence and some behaviour that can be interpreted as supportive and/

brought to reflect a series of identical transactions. Lord Brown noted at [123] that the English practice of requiring each substantive offence to be pleaded separately could lead to 'absurdly overloading the indictment'. In short, this is a pleading point.

96 New Zealand criminal procedure allows representative charges, as in Scotland: see Criminal Procedure Act 2011 (NZ) s 20.

97 (1992) 9 CRNZ 403.

98 Ibid, [409].

99 For example, Speight J noted in $R v$ Willoughby [1980] 1 NZLR 66, [67] that 'charges of conspiracy should be used with discretion'. He suggested that it was improper to charge conspiracy when the essence of the allegation was that a substantive offence had been completed or attempted. Conspiracy should be used for scenarios of agreement without attempt or completion of the offence, though in cases where the evidence was unclear use of conspiracy in the alternative might be proper: $R v$ Dillon and Cowie [1956] NZLR 110. See also $R v$ Hampton [1968] NZLR 948, relying on $R v$ Boulton 12 Cox CC 87, as applied in $R v$ Dawson (1960) 44 Cr App R 87; R v Griffiths (1965) 49 Cr App R 279 and Verrier v DPP [1967] 2 AC 195. Endorsing this, the Court of Appeal in $R v$ Humphries [1982] 1 NZLR 353 indicated that the Court 'looks with disfavour upon the joinder of a count of conspiracy to specific counts which relate to the subject-matter of the conspiracy'. Nonetheless, on the specific facts, the Court allowed joinder of numerous substantive drugs offences and a conspiracy charge because the allegation was like the situation in Henry, namely a wider conspiracy and some mere incidents of it. 
or anti-social might be enough to link an individual accused to a collective agreement to pursue a crime. Once they are found to have joined the agreement the parameters of that agreement may then be assessed by the actions and statements of others in the group - including the actions of the principal in offending. The shared purpose rests largely on the inference that what happens is what was planned.

Serious criminal consequences can follow - consequences that may not have a particularly strong relationship with what it is proven that the particular individual did. The Crown may be able to sidestep the difficulties involved in proving that the defendant was actually a party to any offending that took place by charging them with conspiracy. Alternatively, the very broad interpretive approach taken to the requirements of the common purpose doctrine might mean that they find themselves convicted of extremely serious offending going far beyond what was agreed to. For example, they may be convicted of murder or manslaughter because they felt obliged to support their friends by backing them when they got into a physical confrontation with another group of men.

The extended understanding of group liability in New Zealand case law may result in people who are family members of those involved in criminality, or who are simply on the outskirts of a group which happens to contain someone intent on criminality or an elevated form of criminality, finding themselves convicted because of their failure to actively distance themselves from their associates. In short, they are placed under a legal obligation to recognise that an offence or offences are developing and then take steps to avoid liability - not unlike a duty to act resulting in liability for a failure to do so. ${ }^{100}$

100 Indeed, this may require positive steps to undo what is developing if the rules applicable to withdrawal from secondary liability under s 66(1) are applicable: Ahsin and Rameka $v$ The Queen [2014] NZSC 153, [124]. 